\title{
Potential mutant of Lentinula edodes with high yield of (1-3), (1-6-), $\beta$-D-glucan
}

\author{
Ibrahim Mahmood a, Azhar Mohamad c, Fauzi Daud a, Babul Airianah Othman a, b, Douglas Law e, \\ Yew Hoong Cheah ${ }^{d}$, Mushrifah Idris ${ }^{b}$, Azwan Mat Lazim ${ }^{a}$, b, Seng Joe Lim a, Nur Hidayah

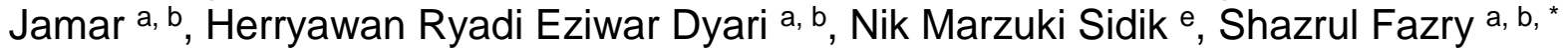 \\ a Fakulti Sains dan Teknologi, Universiti Kebangsaan Malaysia, 43600 Bangi, Selangor, Malaysia \\ b Pusat Penyelidikan Tasik Chini, Fakulti Sains dan Teknologi, Universiti Kebangsaan Malaysia, 43600 Bangi, Selangor, Malaysia \\ c Malaysian Nuclear Agency, Bangi 43000, Kajang, Selangor, Malaysia \\ d ZACH Biotech Depot Sdn. Bhd., 43300 Cheras, Selangor, Malaysia \\ e Faculty of Agro Based Industry, Universiti Malaysia Kelantan, Jeli Campus, Locked Bag 100, 17600 Jeli, Kelantan, Malaysia \\ * Corresponding author: shazrul@ukm.edu.my
}

\section{Article history}

Received 28 December 2018

Revised 22 February 2019

Accepted 4 April 2019

Published Online 15 May 2019

\begin{abstract}
Lentinula edodes or better known as Shiitake mushroom contains $\beta-1,3 ; 1,6$-glucan as part of the cell wall components and studies have shown that it has the ability to enhance the immune system and work as anticancer. The aim of this study was to create potential strain of $L$. edodes with the high content of $\beta-1,3 ; 1,6$-glucan, which has the potential for biotechnological purposes. $L$. edodes spores were irradiated with gamma ray ( $\mathrm{\gamma}$-rays) and incubated, which formed monokaryon mycelium (MM). Compatible mating of mutated monokaryon formed mutant line dikaryon mycelium (MLDM) that was selected for genotypic and phenotypic comparisons with the wild-type line dikaryon mycelium (WLDM). The concentration of $\beta-1,3 ; 1,6$-glucan was measured using a commercial $\beta$-Glucan Megazyme Assay Kit (Yeast \& Mushroom). Three MLDM (A37, A26, and C07) with 38.8, 36.0 and $34.5 \%(\mathrm{w} / \mathrm{w})$ of $100 \mathrm{mg}$, respectively, significantly produced higher amount of $\beta-1,3 ; 1,6$-glucan in comparison with WLDM $(20.2 \%(\mathrm{w} / \mathrm{w})$ of $100 \mathrm{mg})$.
\end{abstract}

Keywords: DM, MM, mutation, ISSR-PCR, Lentinula edodes

\section{INTRODUCTION}

L. edodes fruit body contains $88-92 \%$ water, lipids, proteins, carbohydrates, vitamins and minerals (Solomon, 2004). The ratio of these components is different, depending on parameters used such as the substrate, cultivation method, temperature, humidity, darkness ratio and fruiting condition (Mata et al., 2016), thus affecting the production of bioactive compounds and nutrition value of the mushroom. Dried L. edodes contains 58-60\% carbohydrates, 9-10\% fibres, $20-23 \%$ proteins, $3-4 \%$ lipids and ash $4-5 \%$, and it is different as compared to the raw $L$. edodes. L. edodes is well-known with the higher source of vitamins especially vitamin $\mathrm{B}_{12}$ (Bisen et al., 2010) and D2 (Hiroki et al., 2014). Furthermore, water soluble polysaccharides, known as lentinan have the ability to act as anticancer (Wang et al., 2017).

It is well known that mushroom cell wall is mainly composed of two types of polymers, which are $\beta$-glucan and chitin (Shida et al., 1981; Du et al., 2014). However, mushroom cell wall consists of three layers: heteropolysaccharide and $\beta-1,3 ; 1,6$-glucan as outside layer, $\beta-(1-6)$-glucan with a small number of $\beta-(1-3)$ branches as middle layer, and the inner layer that consisted of $\beta$-glucan and chitin (Bak et al., 2014). The production of $\beta$-glucan is affected by potential interferences agents that presented during fermentation (Crognale et al., 2007).

A previous study showed that the $L$. edodes has the bioactive compound of the $\beta$-glucans (specifically $\beta-1,3 ; 1,6$-glucan)
(Sahasrabudhe et al., 2016). However, the $\beta$-glucans produced are low in solubility, thus chemical modification is done to improve the bioviability of the polysaccharide. Improvement in the functional properties of $\beta$-glucan is done by using the chemical and physical crosslinking reactions (Hatada et al., 1995). $\beta$-glucans can be modified chemically to obtain various derivatives for medicinal and/or potential industrial uses (Synytsya \& Novák, 2013). A previous study reported that the modification in the $\beta$-glucan chemical structure could affect the bioactive properties either negatively or positively (Zeković et al., 2005; Makkar et al., 2007).

The existence of $\beta$-glucan in the cell wall of microorganisms (yeast, bacteria and fungi) and plants has been reported by (Roemer \& Bussey, 1991). Two classes of alkali-insoluble $\beta$-glucan are existed in Saccharomyces cerevisiae, the first is (1-3)- $\beta$-glucan which makes up $25 \%$ of the dried cell wall and the second is (1-6)- $\beta$-glucan which makes up to $7 \%$ of the dried cell wall (Pérez \& Ribas, 2013). Usually, bacteria have different branching classes of $\beta$-glucan which are (1-4)$\beta$-glucan and (1-6)- $\beta$-glucan (17). The (1-3)- $\beta$-glucan is considered as the most common cell wall component in fungi(Roemer \& Bussey 1991). In plants, $\beta$-glucan has been found as (1-3)- $\beta$-glucan callose of cell wall (Roemer \& Bussey, 1991).

There are various techniques that have been applied to produce fungal mutants, for example, mating between monokaryon hyphal (Fukuda et al., 1995), fusion of protoplast between two cells (Yan et al., 1996) and transformation of genes (Godfrey et al., 1994). However, the biggest problem in getting the compatible types of 
mating in fungi is the low regeneration of protoplast (Kawasumi et al., 1988).

The mutation by V-ray has the ability to alter the bases of DNA sequence without changing the genomic sequence of the organism (Sato et al., 2006; Lee et al., 2015). Several studies have shown the changes of specific genes in fungi upon radiation with the $\mathrm{Y}$-rays such as filamentous fungi (Zolan et al., 1988; Boominathan et al., 1990). In this study, $\mathrm{V}$-ray was used to induce mutation in L. edodes in order to get mutants with high content of $\beta-1,3 ; 1,6$-glucan, enabling them to have a great prospect in the biotechnology industry.

\section{EXPERIMENTAL}

\section{Sample preparation and single spore isolation}

Fruit bodies were collected from Kundasang Sabah, Malaysia. After that, the spore print was made from the cap. The spores were scraped and diluted with $100 \mu \mathrm{L}$ of distilled water, then exposed to $\mathrm{V}$ ray with Caesium-137 (by Malaysian Nuclear Agency). Different doses of strength $(0,100,200,300,400,500,600$ and $700 \mathrm{~Gy})$ were used whereas the dose rate was fixed at $13.1 \mathrm{~Gy} \cdot \mathrm{min}^{-1}$. The spores were germinated on freshly prepared potato dextrose agar (PDA) (OXOID, USA), where the media were prepared according to manufacturing manual ( $39 \mathrm{~g}$ of powder was dissolved in one litre of distilled water and autoclaved at 1.05 bar for $15 \mathrm{~min}$ at $121^{\circ} \mathrm{C}$ ). Next, single spore was isolated using cylinder puncher $(0.7 \mathrm{~mm})$. Then, monokaryon mycelium was isolated from germination of single spore and prepared for mating test (Kaur \& Sodhi, 2015).

\section{Mating test}

The mating was carried out by the subculture of two different monokaryon mycelium (MM) on the same PDA plate. By using three different groups of spores, 108 crossings were achieved.

\section{Extraction and measuring of $\beta$-glucan}

Polysaccharides extraction was carried out by using boiling technique from dried mycelium (DM) (Szwengiel \& Stachowiak, 2016). The concentration of $\beta-1,3 ; 1,6$-glucan was determined as described in manual $\beta$-Glucan Assay Kit (Yeast \& Mushroom) (Megazyme). Calculation of the total glucan was done using the equation below:

$$
\text { Total glucan }=a \text {-glucan }+\beta \text {-glucan }
$$

\section{DNA extraction and purification}

Genomic DNA (gDNA) was extracted from $L$. edodes mycelium as previously described by (Singh et al., 2016), where $0.5 \mathrm{~g}$ of freshly collected DM was used for gDNA extraction. Purified gDNA was quantified using (NanoDrop 1000) THERMO SCIENTIFIC ${ }^{\mathrm{CO}}$. and validated using $1 \%$ agarose gel electrophoresis.

\section{ISSR-PCR amplification}

Ten ISSR primers were optimized and used for the detection of polymorphisms (Table 1). The ISSR-PCR analysis was carried out using $4 \mu \mathrm{l}$ of DNA $(50 \mu \mathrm{g} / \mathrm{ml}), 1 \mu \mathrm{l}$ of dNTPs $(10 \mathrm{mM}), 2 \mu \mathrm{l}$ of forward and reverse primers $(10 \mathrm{mM}), 1.5 \mu \mathrm{l}$ of $\mathrm{MgCl}_{2}(25 \mathrm{mM}), 0.1$ $\mu \mathrm{l}$ of Taq DNA polymerase (1.25 units), $5 \mu \mathrm{l}$ of $5 \mathrm{X}$ Reaction Buffer, and $11.4 \mu$ of nuclease-free water (Sigma). The PCR program was as follows: 2 min at $94^{\circ} \mathrm{C}$, followed by 30 amplification cycles $(1 \mathrm{~min}$ at $94^{\circ} \mathrm{C}, 50 \mathrm{sec}$ for primer annealing temperature, and followed by $1 \mathrm{~min}$ at $72^{\circ} \mathrm{C}$ ) and $5 \mathrm{~min}$ at $72^{\circ} \mathrm{C}$ as final extension. The amplified products, which were in $1.5 \%$ agarose gel electrophoresis, were used for PCR products detection (Rashid et al., 2013; Zhao et al., 2016).

\section{Mutants selection of $L$. edodes}

Mutant line dikaryon mycelium (MLDMs) were selected based on the changes or presence of ISSR-DNA bands while the growth performance of mushrooms was compared to wild-type line dikaryon mycelium (WLDM). Growth performance assay was carried out as described previously by (Ibrahim et al., 2017). All data was analysed with ANOVA using SPSS v.22.
Table 1. List of ISSR Primers and melting temperature.

\begin{tabular}{lll}
\hline Primer no. & Primer sequencing (5'-3') & Tm $\left({ }^{\circ} \mathbf{C}\right)$ \\
\hline IS1 & (CAC)7T (22 mer) & 45 \\
IS 10 & BDBT(CCT)6 (18 mer) & 63 \\
IS11 & HVH(TCC)6 (20 mer) & 45 \\
IS 12 & (AG)8T (19 mer) & 45 \\
IS 13 & (AG)8G (17 mer) & 45 \\
IS 14 & (GA)8T (17 mer) & 45 \\
IS16 & (GA)8A (17 mer) & 45 \\
& (TG)8A (17 mer) & 45 \\
IS 47 & (ACC)6 (18 mer) & 45 \\
IS 72 & 5' (GTC)5 3' (15 mer) & 45 \\
\hline
\end{tabular}

Notes: $B=C, G, T ; D=A, G, T ; H=A, C, T ; R=A, G ; V=A, C$, $\mathrm{G} ; \mathrm{Y}=\mathrm{C}, \mathrm{T}$

\section{RESULTS AND DISCUSSION}

\section{Growth performance of single spore}

The irradiated spores did not show any differences in growth performance after 14 days of germination. The $\mathrm{Y}$-rays did not affect the growth performance of MM isolated from spores.

\section{Mating of MM}

In this study, 15 MLDM were successfully produced by crossing 108 irradiated MM. Compatibility test was carried out by observing the migration of MM to each other on PDA plate, as well as by using the microscope to observe the formation of clamps (Figure 1). The compatible mating had a higher number of clamps formation as compared to incompatible mating. Normally, compatible mating would produce 5-6 number of clamps/HPF whereas incompatible mating would only produce 0-2 number of clamps/HPF. (Lee et al., 2000) suggested that the higher number of clamps would increase the formation of fruit body. Besides, incompatible mating would grow and form an atypical circle (butterfly-like), producing two different circles, and thus, reducing the chances of mating and the formation of clamps (Figure 2).
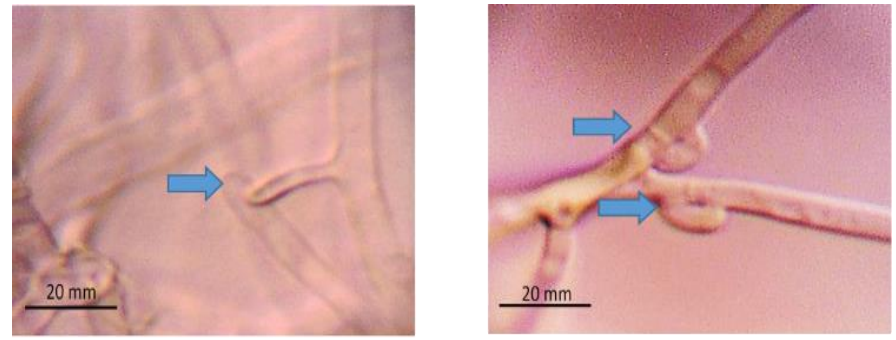

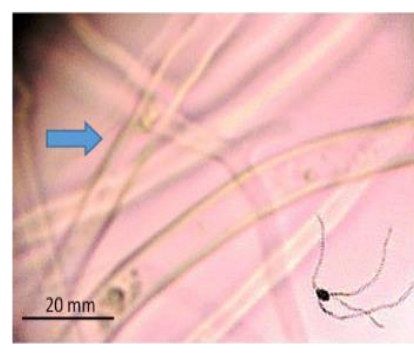

Incompatible mating

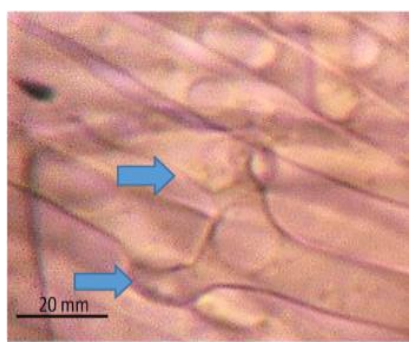

Compatible mating
Fig. 1 Observation of clamps formation. The left pictures show the low clamps formation of incompatible mating, the right pictures show the high clamps formation of compatible mating. (The blue arrows refer to the clamps in right and hocking of mycelium in left). The clamps were observed at 40X magnification power. Unlike the incompatible mating, compatible mating showed higher number of clamps. 


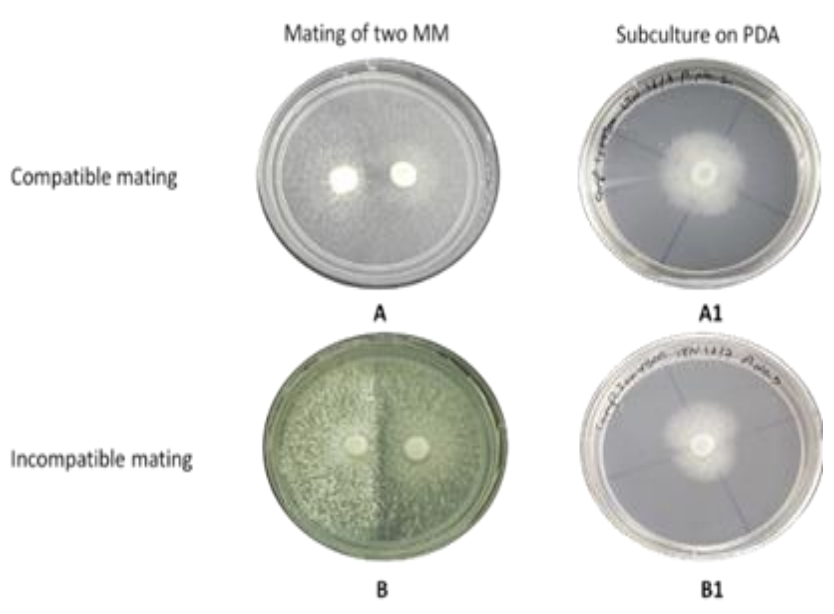

Fig. 2 Macroscopically observation for mating. (A) The morphology of compatible mating of monokaryon mycelia (no separation of mycelia was observed in the compatible mating culture), (B) Incompatible mating of mycelia (distinct "butterfly" morphology was observed due to the rejection of two mycelia at the mid line which would prevent mating, (A1) Continuous sub-culturing formed a typical circle, and the last (B1) Continuous sub-culturing formed an atypical circle (butterfly phenomena). The sub-culture was done by using freshly prepared PDA and $0.7 \mathrm{~mm}$ cylinder puncher.

\section{Growth performance}

WLDM has slower growth performance as compared to the 15 isolated MLDM. The growth performance of shiitake was $8.4 \mathrm{~cm} / 14$ days, while certain potential mutant lines (MLDM) showed faster growth performance in comparison with WLDM. The faster growth performance of some MLDM was due to the effects of $\mathrm{Y}$ - rays which produced some changes in the genetic materials of the mushroom $(\mathrm{Fu}$ et al., 2008). Besides, previous study has also shown that the growth performance of $L$. edodes was associated with the cell wall content, especially laccase and cellulose although the expressions of both these enzymes were not similar at the same time (Synytsya \& Novák, 2013).

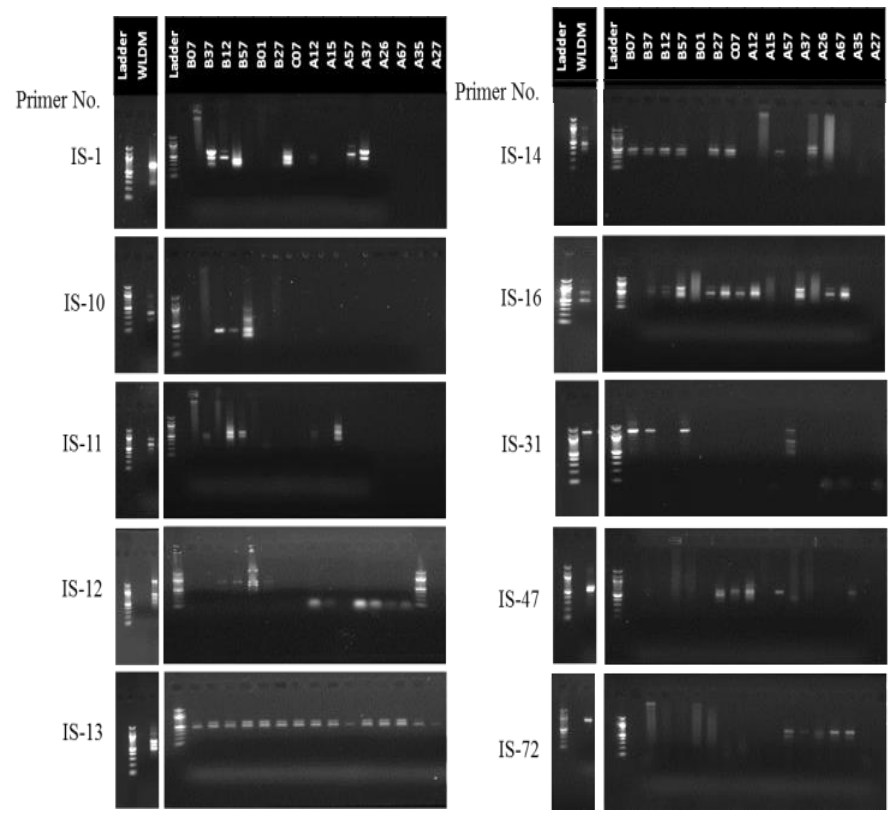

Fig 3 Electrophoresis result of ISSR-PCR. The PCR products were run with $1.5 \%$ agarose gel, after mixing $20 \mu \mathrm{l}$ of products with $5 \mu \mathrm{l} 6 \mathrm{X}$ blue dye (PROMEGA). The results were determined by observing the bands (presence, absence and shifting).

\section{Observing the phenotypic and genotypic variation of DM}

Genetic variation was determined by observing the presence, absence and shifting of bands of ISSR-PCR products (Figure 3).
According to (Malekzadeh et al., 2014), ISSR primers were powerful enough for the detection of polymorphism among closely related genotypes which could be used for fingerprinting and legal ownership. It has been used as a molecular tool to identify the genotype variation in different strains of button mushroom (Agaricus bisporus) and this method could compare the differences between WLDM and MLDM by observing the existence of specific bands from different primer combinations. The results have shown that all 15 MLDM were different in comparison with WLDM (Figure 2). Interestingly, phenotypic variations of some MLDM which showed the fluffy and rigid DM (mutant B12, B01, C07, A12 and A37) were different from the WLDM (Figure 4). Study on irradiated Pleurotus Ostreatus which produced fluffy mycelium did not affect the growth performance in comparison with wild mycelium (Sharma \& Sharma, 2014). Furthermore, mycelium rigidity was due to the change in the lignin composition of mycelium which affected the mycelium structure (Saidu et al., 2015)

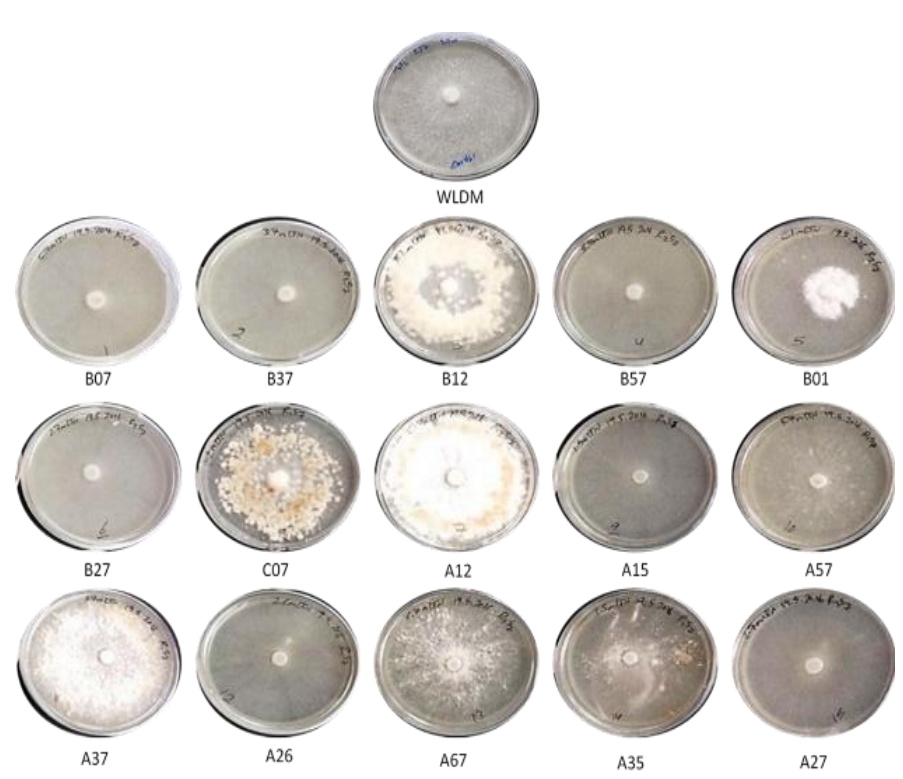

Fig. 4 Phenotypic variation. All DM at 25 days after subculture, some of the WLDM showed phenotypic differences in comparison with WLDM. $B 12, B 01, C 07, A 12$, and $A 37$ were shown to be rigid, fluffy and white mycelium in comparison to WLDM.

\section{Determination of $\beta-1,3 ; 1,6$-glucan}

Dried metabolites were extracted from dried mycelium to investigate the effects of $\gamma$-rays on the production of $\beta-1,3 ; 1,6$-glucan. The findings showed noteworthy results by comparing the concentration of $\beta-1,3 ; 1,6$-glucan from three of the MLDM, which were $38.8,36.0$ and $34.5 \% \mathrm{w} / \mathrm{w}$ of $100 \mathrm{mg} \mathrm{dm}$, whereas the WLDM produced $20.2 \% \mathrm{w} / \mathrm{w}$ of $100 \mathrm{mg} \mathrm{dm}$ (Table 2). Recent study has also shown similar results for the wild-type L. edodes (Sari et al., 2017). Exposing the $\mathrm{V}$ - rays to $2.0 \mathrm{KGy}$ could soften cell wall structure by changing the activity of several enzymes of the fruit body, either by decreasing (negative effects) or increasing (positive effects) the concentration of $\beta-1,3 ; 1,6$-glucan, and thus, affecting its production (Jiang et al. 2010). Our results showed the highest amount of $\beta$ 1,3;1,6-glucan in A37 mutant (positive effects) with $38.8 \% \mathrm{w} / \mathrm{w}$ of $100 \mathrm{mg} \mathrm{dm}$, while the lowest amount was in A35 mutant which produced $13.3 \% \mathrm{w} / \mathrm{w}$ of $100 \mathrm{mg} \mathrm{dm}$ (negative effects).

\section{CONCLUSION}

Three L. edodes mutants (A37, A26 and C07) were successfully mutated to produce a higher amount of $\beta-1,3 ; 1,6$-glucan (at least 1.5 times more) compared to the wild-type strain via $\gamma$-ray radiation. We proposed that it was easier, faster and cheaper to use $\mathrm{Y}$-rays in order to produce new mushroom breed with higher amount of desired active compound (in this case $\beta$-1,3;1,6-glucan) for future purposes. 
Table 2. Total glucan concentration of Lentinus edodes mutants and wild lines.

\begin{tabular}{|c|c|c|c|}
\hline Sample no. & Total glucan & a-glucan & $\beta$-glucan \\
\hline B07 & 27.6 & 2.7 & 24.9 \\
\hline B37 & 19.1 & 1.8 & 17.3 \\
\hline B12 & 19.0 & 1.3 & 17.7 \\
\hline B57 & 21.1 & 2.0 & 19.1 \\
\hline B01 & 15.4 & 1.4 & 14.0 \\
\hline B27 & 18.9 & 1.7 & 17.2 \\
\hline $\mathrm{C} 07$ & 38.1 & 3.6 & 34.5 \\
\hline A12 & 27.3 & 2.9 & 24.4 \\
\hline A15 & 34.7 & 3.2 & 31.5 \\
\hline A57 & 28.0 & 2.5 & 25.5 \\
\hline A37 & 43.0 & 4.2 & 38.8 \\
\hline A26 & 40.0 & 4.0 & 36.0 \\
\hline A67 & 32.4 & 3.2 & 29.2 \\
\hline A35 & 14.8 & 1.5 & 13.3 \\
\hline A27 & 15.0 & 1.6 & 13.4 \\
\hline WLDM & 22.4 & 2.2 & 20.2 \\
\hline
\end{tabular}

* concentration measurement unites $(\% \mathrm{w} / \mathrm{w}$ for $100 \mathrm{mg})$

\section{ACKNOWLEDGEMENT}

We would like to acknowledge the Malaysian Nuclear Agency and ZACH Biotech Depot Sdn. Bhd. for their cooperation and permission to access to their facilities. We would also like to thank Universiti Kebangsaan Malaysia (UKM) and Pusat Penyelidikan Tasik Chini (PPTC), UKM for providing us the grant (LIV-2015-05) and space for our mushroom farm.

\section{REFERENCES}

Bak, W. C., Park, J. H., Park, Y. A., Ka, K. H. 2014. Determination of glucan contents in the fruiting bodies and mycelia of Lentinula edodes cultivars. Mycobiology. 42, 3, 301-305.

Bisen, P. S., Baghel, R. K., Sanodiya, B. S., Thakur, G. S. \& Prasad, G. 2010 Lentinus edodes: A macrofungus with pharmacological activities. Curr Med Chem. 17, 22, 2419-2430.

Boominathan, K., Dass, S., Randall, T. 1990. Nitrogen-deregulated mutants of Phanerochaete chrysosporium-A lignin-degrading basidiomycete. Arch. Microbiol. 153, 6, 521-527.

Crognale, S., Bruno, M., Fidaleo, M., Moresi, M. \& Petruccioli, M. 2007. Production of $\beta$-glucan and related glucan-hydrolases by Botryosphaeria rhodina. J Appl Microbiol. 102, 3, 860-871.

Du, B., Bian, Z., Xu, B. 2014. Skin health promotion effects of natural betaglucan derived from cereals and microorganisms: A review. Phytother Res. 28, 2, 159-166.

Fu, H. -W., Li, Y. -F., Shu, Q. -Y. 2008. A revisit of mutation induction by gamma rays in rice (Oryza sativa $\mathrm{L}$.): Implications of microsatellite markers for quality control. Mol. Breed. 22, 2, 281-288.

Fukuda, M., Harada, Y., Imahori, S., Fukumasa-Nakai, Y., Hayashi, Y. 1995. Inheritance of mitochondrial DNA in sexual crosses and protoplast cell fusions in Lentinula edodes. Curr. Gene. 27, 6, 550-554.

Godfrey, B., Akileswaran, L., Gold, M. 1994. A reporter gene construct for studying the regulation of manganese peroxidase gene expression. Appl Environ Microbiol. 60, 4, 1353-1358.

Hatada, M. H., Lu, X., Laird, E. R., Green, J., Morgenstern, J. P., Lou, M., Marr, C. S., Phillips, T. B., Ram, M. K., Theriault, K. 1995. Molecular basis for interaction of the protein tyrosine kinase ZAP-70 with the T-cell receptor. Nature. 377, 6544, 32-38.

Hiroki, Sh., Catherine, P., Randi, V., Paolo, M., Bojana, P., Jianqing, X., John, P.O., Kazunori, H., Shinji, S., Kazuhisa, T., Dominic, C., Marie-Paule L. K. I., 2014. Antibody informatics for drug discovery. Biochim Biophys Acta Proteins Proteom. 1844, 11, 2002-2015.

Ibrahim, M., Mohamad, A., Daud, F., Kadir, Z. A., Nie, H. J., Hussain, H. H., Safina, W., Razak, W. A., Airianah, O. B., Fazry, S. 2017. Variants production of Lentinula edodes spores, monokaryon mycelium and dikaryon mycelium by $\mathrm{Y}$-irradiation. Malays Appl Biol. 46, 1, 77-82.

Jiang, T., Luo, S., Chen, Q., Shen, L., Ying, T. 2010. Effect of integrated application of gamma irradiation and modified atmosphere packaging on physicochemical and microbiological properties of shiitake mushroom (Lentinus edodes). Food Chem. 122, 3, 761-767.

Kaur, A. \& Sodhi, H. S. 2015. Characterization of single spore isolates of Volvariella volvacea (Bulliard: Fries) Singer. J. Appl. Hortic. 17, 3, 236240.

Kawasumi, T., Baba, T. \& Yanagi, S. 1988. Protoplast fusion of incompatible mating type combinations of Lentinus edodes (Shiitake) auxotrophs. Agr Biol Chem. 52, 12, 3197-3199.

Lee, K. J., Kim, J. B., Choi, H. I., Ha, B. K., Kang, S. Y., \& Kim, D. S. (2015) Selection of soybean mutant lines with altered seed coat colour and their antioxidant activity. Plant Breeding, 134(5), 573-579.

Lee, Y. K., Chang, H. H., Kim, J. S., Kim, J. K. \& Lee, K. S. 2000. Lignocellulolytic mutants of Pleurotus ostreatus induced by gamma-ray radiation and their genetic similarities. Rad. Phys. Chem. 57, 2, 145-150.

Makkar, H. P. S., Siddhuraju, P. \& Becker, K. Glucosinolates. Humana Press, Totowa, 2007, p.55.

Malekzadeh, K., Mohsenifard, E. \& Jalalzadeh, M. 2014. Identification and strain-typing of button mushroom using ISSR, ITS and IGS markers. Mod Genet J. 2014, 2014, 343-352.

Mata, G., Salmones, D. \& Pérez-Merlo, R. 2016. Hydrolytic enzyme activities in shiitake mushroom (Lentinula edodes) strains cultivated on coffee pulp. Revi. Argen. de Microb. 48, 3, 191-195.

Pérez, P. \& Ribas, J. 2013. Fungal cell wall analysis. Laboratory Protocols in Fungal Biology, Springer, New York.

Rashid, R. A., Mohamad, A., Awang, M. R., Mutaat, H. H., Mohamad, S. A., Hasan, A. A., Maskom, M. M. and Nahar, S. K. M. (2013). Isolation and optimization of inter-simple sequence repeat (ISSR) technique for Pleurotus sajor caju towards enviromental study in support of the country's nuclear power programme. Jurnal Sains Nuklear Malaysia, 25(1), 1-8.

Roemer, T. \& Bussey, H. 1991. Yeast beta-glucan synthesis: KRE6 encodes a predicted type II membrane protein required for glucan synthesis in vivo and for glucan synthase activity in vitro. Proc Natl Acad Sci U S A. 88, 24, 11295-11299.

Sahasrabudhe, N. M., Tian, L., van den Berg, M., Bruggeman, G., Bruininx, E., Schols, H. A., Faas, M. M. \& de Vos, P. 2016. Endo-glucanase digestion of oat $\beta$-Glucan enhances Dectin-1 activation in human dendritic cells. $J$ Funct Foods. 21, 104-112.

Saidu, M., Busari, A., Yuzir, A. \& Salim, M. 2015. Effect of oyster mushroom on biodegradation of oil palm mesocarp fibre. Int J Environ Ecol Eng. 9, 10, 1248-1252.

Sari, M., Prange, A., Lelley, J. \& Hambitzer, R. 2017. Screening of betaglucan contents in commercially cultivated and wild growing mushrooms. Food Chem. 216, 2017, 45-51.

Sato, Y., Shirasawa, K., Takahashi, Y., Nishimura, M. \& Nishio, T. 2006 Mutant selection from progeny of gamma-ray-irradiated rice by DNA heteroduplex cleavage using Brassica petiole extract. Breed. Sci. 56, 2, 179 183

Sharma, R. \& Sharma, B.M. 2014. Strain improvement in Pleurotus Ostreatus using UV light and ethyl methyl sulfonate as mutagens. Afr J Microbiol Res. $8,5,432-436$.

Shida, M., Ushioda, Y. \& Nakajima, T. 1981. Structure of the alkali-insoluble skeletal glucan of Lentinus edodes. J Biochem. 90, 4, 1093-1100.

Singh, N. M., Singh, W. R. C., Singh, H. B. \& Singh, W. N. 2016. DNA extraction from Siroi lily (Lilium mackliniae)-an endangered species using CTAB method. Euro J Exp Biol. 6, 4, 38-40.

Solomon, W. P., In: Coates, P. M., Paul, M. C., Blackman, M., Blackman, M. R., Cragg, G. M., Levine, M., White, J. D., Moss, J. \& Levine, M. A (Eds.) Encyclopedia of Dietary Supplements, CRC Press, Florida, 2004, p. 653-664.

Synytsya, A. \& Novák, M. 2013. Structural diversity of fungal glucans. Carbohydr Polym. 92, 1, 792-809.

Szwengiel, A. \& Stachowiak, B. 2016. Deproteinization of water-soluble Bglucan during acid extraction from fruiting bodies of Pleurotus ostreatus mushrooms. Carbohydr Polym. 146, 310-319.

Wang, Y., Xu, G., Tang, X. \& Chen, H. 2017. Polysaccharide lentinan extracted from the stipe of Lentinus edodes mushroom exerts anticancer activities through the transcriptional regulation of cell cycle. FASEB J. 31, Abstract No. lb391.

Yan, K., Zhu, B., Cheng, Y., Li, Q. \& Zhao, H. 1996. Transformation of Pleurotus sapidus protoplasts by electroporation. Chin J Biotechnol. 12, 4, 40-44.

Zeković, D. B., Kwiatkowski, S., Vrvić, M. M., Jakovljević, D. \& Moran, C. A. 2005 . Natural and modified $(1 \rightarrow 3)-\beta$-D-glucans in health promotion and disease alleviation. Crit Rev Biotechnol. 25, 4, 205-230. 
Zhao, H., Wang, Y., Yang, D., Zhao, X., Li, N. \& Zhou, Y. 2016. An analysis of genetic diversity in Marphysa sanguinea from different geographic populations using ISSR polymorphisms. Biochem Syst Ecol. 64, 65-69.

Zolan, M. E., Tremel, C. J. \& Pukkila, P. J. 1988. Production and characterization of radiation-sensitive meiotic mutants of Coprinus cinereus. Genetics. 120, 2, 379-387. 